\title{
医療政策ヒストリー座談会 第6回「2002（平成14）年健康保険法等改正」
}

\section{丹或泰健氏 インタビュー \\ 2020年 3 月 5 日（木） 16:30 18:00 \\ 於：医療科学研究所会議室}

聞き手) 新田 秀樹 (主任研究者, 中央大学法学部教授)

島崎 謙治（アドバイザー, 政策研究大学院大学教授)

三谷宗一郎 (研究補助者, 医療経済研究機構協力研究員

／サントリー文化財団鳥井フェロー）

江利川 毅 (監修, 公益財団法人医療科学研究所理事長)

江利川 本日はありがとうございます。この医 療政策ヒストリー座談会というプロジェクトは, 医療関係の制度改正について，当時の担当者に背 景や経過などを伺っています。当時の解説本には 書かれていないようなことや，こういうことを考 えたけれどもやめたというようなことも聞いて, 記録に残すというようなことをしています。対象 とする制度改正は, 高度経済成長が終わり, 予算 が増えなくなり，一方で高齢化によって医療需要 が大きくなった時期，すなわち1980年代（昭和55 〜平成元年）以降です。2000（平成12）年の介護 保険がスタートする頃までの改正は, 大括りに言 えば, 政府内部において, 需要増に財政事情を踏 まえつつ厚生省がどう対応するかを考え，大蔵省 と相談しながら方針を作っていったという形だと 思います。2000年を過ぎてからは，経済財政諮問 会議ができて，政策が官邸主導で動いていくよう になり，各省のトップレベルの出番が多くなりま した。2000年までの改正は課長や課長補佐を中心 に座談会を行いましたが，今回は大塚（義治）局
長や中村 (秀一) 審議官といったレ ベルの方に集まっ ていただいて座談 会を行うことにし ました。そして 本日は, 官邸の要 の小泉総理大臣の 秘書官であった丹 点さんにお話を伺 いたいということ でインタビューを

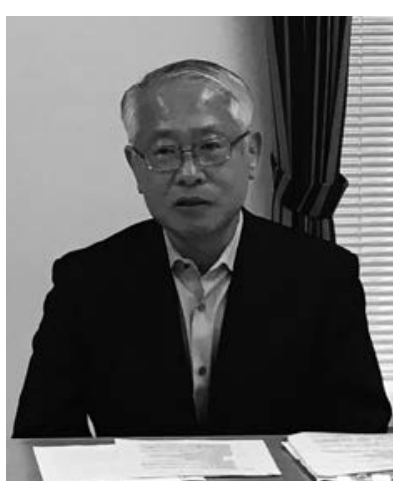

丹吳 泰健氏

1974年大蔵省入省。2001年 4 月～ 2006年 9 月内閣総理大臣秘書官 (小 泉純一郎首相)。2009年～2010年財 務事務次官
お願いしました。快くお引き受けいただきありが とうございます。よろしくお願いします。

\財務官僚として医療政策に感じていたこと

丹吳 ありがとうございます。よろしければ最 初に少し私から括をさせて話をただこうかと思っ ています。

財務省には主計局に主査という各省の予算を担 
当するポストがあります。厚生省予算には福祉, 医療，年金それぞれに担当主査がおりました。私 は1986（昭和61）年の年金法大改正の時, 途中か ら主査として担当いたしました。亡くなられた山 口（剛彦）さんが年金課長として活躍されていま した。1994（平成 6）年から97（平成 9）年にか けて主計官を務め, そこで初めて医療を担当しま した。すぐに診療報酬改定がありましたね。それ から, 事務次官の岡光（序治）さんと介護保険の 話をしていたら，途中でああいう事件注1) があり ました。山口保険局長と医療制度改革をどうしょ うかとお話をしていたら, 代わられて, 高木（俊 明）さんが保険局長になりました。

年金はかなり理論的にできるのですが，医療の 場合は必ずしもそうではないのだなと感じまし た。それを強く感じたのは, カントリードラッグ の件でした。薬価改定の対象となる薬の中に，日 本でしか通用しない薬があると。東大の先生や厚 生省の薬務局長にも話を聞きました。ある脳循環 代謝改善薬です。最終的にはメーカーが, 薬価改 定の対象から下ろすということになりました。大 学の先生からは「データがどうもおかしい」と聞 きました。ライバルの製薬会社の方に伺うと,「確 かに国際的には認められない薬です」とも聞きま した。なぜそういうものがあったのか。年金と医 療とではだいぶ違うなと感じました。

それから, 薬として承認されるとなぜすぐに保 険収載されるのか。確かあの頃は政管健保の財政 がかなり厳しくなっていました。薬に収載される とただちに保険に掲載する，という仕組みについ て，「保険財政にどう影響を与えるのかを考えた

注1）ああいう事件：1996（平成 8）年に起こった厚生官 僚による特別養護老人ホームをめぐる污職事件。当 時, 厚生事務次官の岡光序治氏らが埼玉県の社会 福祉法人に対して補助金交付などの便宜を図り，そ の見返りに金品を受け取っていた。事件が発覚した 同年11月，岡光氏の辞任を受けて，保険局長の山口 剛彦氏が事務次官に, 児童家庭局長の高木俊明氏 が保険局長にそれぞれ就任した。
上でやるべきではないか」と言いました。薬務局 が承認すると, 医療課で点数の議論が始まってい ましたから。それは少し早いのではないかという ことでした。

それから, 初めて診療報酬の改定にも関わりま した。非常に政治的なものですね。診療報酬で決 めるのはP (価格) です。Q (使用量) のほうは 決めません。医療課のほうから,「医療費に与え る影響はこのくらいです」と言われるのですが, Qのほうがコントロールできていないと，実際の 影響がどうなるかは分かりません。例えばある薬 の単価が下がっても, 今までより処方量が増えた らどうなるのか。総体として医療費をコントロー ルするには十分ではないのではないかと，財政当 局としては考えていました。 7 対 1 の病床が非常 に増えて問題になったこともありました。

しかしながら，医療では年金以上にプレーヤー がたくさんいます。非常に難しい世界だなと感じ ました。政管健保が特に厳しい時でしたから，高 木保険局長と相談して薬の上乗せ注 2 ) 導入しま した。私どもも国会に呼ばれましたね。理想的な 案というよりも，当面はこれをしないといけない ということでやった記憶があります。

それから医療の場合には国保も政管健保も健保 組合もあります。「皆保険」といいつつも，それ ぞれに保険の仕組みは違います。国保のことにつ いては, 自治省と相談しないといけませんでした。 それから, 日本医師会, 日本看護協会もあります ね。なかなか難しい世界だなと感じていました。

\section{小泉内閣における医療保険制度改革の軌跡}

丹吳 小泉内閣発足後の医療保険制度改革の過 程について，私のメモに即してお話しします。あ くまで私の記憶ですので, どれだけ正しいのかは

注2) 薬の上乗せ：1997（平成 9) 年に行われた健康保険 法等改正において, 通常の定率負担とは別に外来の 薬剤について種類数や日数に応じて患者が定額を支 払う薬剤一部負担金制度が導入された。 
分かりません。

2001（平成13）年 4 月26日に小泉内閣が発足し ました。5月 3 日に各省の次官から総理に説明を していただくという機会がありました。説明は建 制順でやっています。厚生労働省の時間はあまり ありませんでした。総理が言われた言葉でメモを していたのは,「老人医療は無駄が多く, カット が足りない。仕組みを変えるべきではないか」と いうものでした。それから，労㗢分野にも関係が ありますが，「終身雇用の変化に合わせた制度の 見直しをしなくてはならない」ともおっしゃって いました。「年金保険料の早期引き上げが必要だ」 という説明に対して，疑問を呈されました。

5 月 7 日に第151回国会所信表明演説が行われ ました。あの時江利川さんは官邸の首席内閣参事 官でしたでしょうか。

江利川 いえ，私は内閣府の官房長でした。

丹吳 官房長でしたか。この時の演説では総理 が言葉を選ばれました。下から上がってきたわけ ではありません。「これからは『給付は厚く，負 担は軽く』というわけにいきません。」という言 葉を盛んに使っておられました。それから，「社 会保障の三本柱である年金, 医療, 介護について は『自助と自律』の精神を基本とし，世代間の給 付と負担の均衡を図りお互いが支えあう，将来に わたり持続可能な, 安心できる制度を再構築する 決意です」とおっしゃっていました。「自立」で はなく，この「自律」を好んでおられました。

それから，かなり早い時期でしたが，私が坪井 (栄孝) 日本医師会会長と話をする機会がありま した。その時に会長が言われたことで私がメモし ていたのは,「医療への株式会社参入は, 個人と しても医師会としても反対」ということでした。 どうしてこういう話題になったのかは覚えていま せん。総合規制改革会議に抢いて，いろいろな分 野で株式会社参入を考えないといけないという話 が出ていたからではないかと思います。

こちらから，「レセプトの電算化はやりたい」
とお伝えしたところ，「個人としては分かるが医 師会としてすぐうんと言えない」とおっしゃいま した。それから, 財務省など一部で枠を決める「総 枠制」の話が出ていましたが, これは「診療所の 反対が強く無理だ」とおっしゃっていました。ま

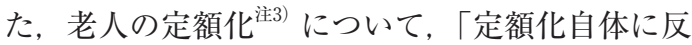
対ではないが，どの水準にするかが問題である」 とおっしゃいました。そして，「薬価について自 分たちは関与しない。政府と製薬業界で決めれば よい」という言い方をされました。

厚生労働省の皆さんの座談会でもあったと思い ますが, 政管健保が大変なので健保法の改正をし なければならないという状況であったかと思いま す。 8 月 3 日に近藤（純五郎）事務次官, 大塚保 険局長から医療改革について総理に説明していた だく機会がありました。30分程度の予定だったの ですが，日程がずれ込んだため，10分強の短時間， 総理が説明を聞かれるという形になりました。検 討事項を局長が説明され，次官が「医療は金がな く困っています」と近藤流にぼやいておられまし た。

そして, 経済財政諮問会議の報告が出た後の話 ですが，9月13日に坂口（力）厚生労働大臣が雇 用対策，医療改革について総理へ説明に来られま した。総理は,「診療報酬のマイナスは当然。改 革全体としてもっと給付の無駄を省くべきで負担 増が目立ちすぎる」と, 大変厳しい口調で言われ ました。それがメモに残っています。

9 月27日に第152回国会所信表明演説が行われ ました。医療のところだけ取り出してみますと, 「特に医療制度については，将来にわたり持続可 能な制度として再構築するため本年末には改革案 を取りまとめ, 来年の通常国会に所要の法律案を 提出すべく全力を尽くします」という言い方をさ れました。改革をやり，来年の国会には法案を出

注3）老人の定額化：増嵩する老人医療費の適正化が当時 の主要な政策課題の一つであり, 包括払い方式や定 額払い方式の拡大などが検討されていた。 
すと明言されたという形です。

そして11月 1 日です。竹島 (一彦) 官房副長官 補, 近藤次官, 大塚局長, 財務省が総理に説明を した時の話です。総理は「医療改革は道路公団改 革より難しいな。1997 (平成 9 ) 年から1998（平 成10）年にかけて, 自分が大臣の時に議論したこ とが全く進捗していない」と強い不満を示されま した。「俺が言ったことが全然できていないじゃ ないか」ということでした。診療報酬については 「中長期のあるべき姿を見据えて, 今回の引き下 げを検討してくれ」と指示されました。その後, 副長官補が今後の段取りを説明されました。この 言葉は印象に残っています。

11月 7 日, 政府与党社会保障改革協議会が終 わった後, 総理は宮下（創平）座長, 長勢（甚遠） 議員, 安倍 (晋三) 官房副長官を呼び止め, 竹島 副長官補, 大塚局長が同席する形で「改革を先送 りせず，あるべき姿を確定した上で平成14年度改 革をしてもらいたい」とおっしゃいました。この 時に，「文字通り三方一両損で中期的には国民に プラスとなるのだという改革内容としてもらいた い」と指示されました。自分のメモでは, ここで 初めて総理が「三方一両損」という言葉を使って います。総理が秘書官と打ち合わせて「三方一両 損」と言ったわけではありません。歴史の好きな 方ですから, 何かで気が付いて使われたのだと思 います。それから, 竹島副長官補が今後の段取り を示しました。そして宮下座長が歴代厚生大臣, 厚生労働大臣の集まりを開いてはどうかという提 案をされたのだと思います。最初に言われたのは 事務方のほうかもしれませんが。どなたの発言か は分かりませんが,「丹羽（雄哉）氏, 津島（雄二） 氏も取り込もう」ということも言われました。そ して，9日に経済財政諮問会議があり，その後， 夜に歴代厚生労働大臣会合が開催されました。

9 日の経済財政諮問会議で, 総理は「規制改革 の検討に当たり, これからは医療, 国立大学, 農 業の分野にも株式会社の参入をモデル的に認める
ことでやってもらいたい」とはっきり指示されま した。この時, トヨタの奥田 (碩) 議員が「薬は 株式会社である製薬会社が競ってよい薬を開発し ている。ところが医療では，良い医療ができない からという理由で株式会社が参入できない。これ はおかしい」と，民間人らしく発言されました。 総理は「それはそうだなあ」と，この発言をいた く気に入っておられました。この点について，坪 井会長の発言にもあるように, 日本医師会は「ダ メだ」と昔から言っていたわけですが。総理は奥 田さんの意見を聞いた後,「医師会の主張は論理 的ではないな」という印象を持っていたように思 います。

その後, 歴代厚生労働大臣会合が開かれました。 総理はあまり細かいことを言わず，「来年は選挙 がないから改革を先送りせず，しっかりした改革 をやるべきである。自分が厚生大臣の時以来の積 み残しを何とかこの機会に処理したい」と発言さ れました。丹羽さんや津島さんを斢制した形です ね。津島議員は「たばこ税の増税を議論すべき。 また診療所と病院を分けて考えるべき」だと発言 されました。やはりface-to-faceでやると和やかで 一致団結して改革に取り組もうとなるものだなと 思いました。この時, 橋本 (龍太郎) さんは出て こられなかったと思います。

それから11月20日に坪井会長が米国医師会会長 を総理に面会させた時，会長は「小泉改革は支持 します。1800億円の財源不足は診療報酬引き下げ で出します。しかし皆保険は守る, また混合診療 と自己負担引き上げは反対です」と率直に言われ ました。なぜ1800億円かというと, 厚生省の方々 の座談会録で読みましたが, もともと2800で, 1000はほかの財源で出る。残りは1800だと。それ をなぜか坪井会長も分かっていました。それは診 療報酬の改定で出すと言われたわけです。総理は それを聞かれるのみでした。

そして, 11月28日の朝, 総理に昨夜塩川（正十 郎）財務大臣, 坂口大臣, 丹羽議員が会ったこと 
を報告しました。総理から指示された 4 項目が あったのですが，内容が何だったのかははっきり しません。次に宮下座長, 長勢議員が, 福田（康 夫）官房長官，安倍副長官，竹島副長官補が同席 する形で，自民党がまとめようとしているペー パーを総理に説明しました。その後，皆で「診療 報酬の引き下げ， 3 割負担，伸び率管理は具体性， 担保力のあるものとする」という内容を総理指示 とすることを確認しました。手順としては，総理 から麻生（太郎）政調会長，山崎（拓）幹事長に 電話することとなりました。総理はまず政調会長 に電話し, 取りまとめに当たるよう依頼しました。 そして，幹事長には「政調会長にはすでに求願い したのでよく相談してもらいたい」という言い方 でお願いされました。宮下座長が党に帰り報告を すると，党側は「診療報酬の引き下げは了承する が，伸び率管理は法定しない。3 割負担より保険 料引き上げの 1 年前倒しをする」と主張しました。 丹羽さんなどの持論だと思います。

この日にはいろいろな動きがありました。副長 官が総理室に飛び込み，党の議論を報告し，「こ れから自民党 11 人委員会がある。宮下座長が妥協 しないよう総理からすぐに電話をしてください」 と依頼されました。総理は宮下座長に電話し「ま とめなくてよい。上に持ってくるようにしてほし い」と指示されました。私に対しては,「事務方 が麻生さん, 山崎さんに問題点をよく説明するよ うに」と指示されました。

総理は以前から「3 割に統一するべきだ。俺は 3 割以上に負担を上げることはしない。3 割まで でバラバラになっているのはおかしい」と言って おられました。総理はその日，山崎幹事長と夕食 を共にされて, 帰りの車中で私に「明日，三役で 3 割負担を決める。坂口大臣にもそうなることを 言いふくめてくれ」と指示されました。坂口さん が丹羽さんと懇意なのは分かっておられましたか ら。

11月29日の朝, 総理は安倍副長官, 竹島副長官
補，大塚局長から前日夜の自民党との折衝経過を 聞き，その日のうちに党五役会議を開くことを決 められました。昼に, 総理は山崎幹事長, 麻生政 調会長, 宮下座長, 安倍副長官から「党は平成15 （2003）年からも 3 割負担はダメで保険料の前倒 しを主張」との報告を聞きました。麻生政調会長 は「下からの議論を無視できない」と言われまし た。そして, 党五役会議に丹羽, 長勢議員が参加 することを了解されました。

同日に開かれた党五役会議では, 丹羽さんが「 3 割負担は反対だ。9月以来の議論の積み重ねの上 での結論である」と手続きの正当性も併せて主張 されました。「認められなければ責任を取れない」 とまで述べられました。長勢議員がそれに同調さ れました。宮下座長は「個人的には 3 割負担が適 切」との言い方をされました。山崎幹事長は「3 割負担は, 公明党, 野田（毅）保守党党首も賛成 する」と報告されました。丹羽議員が繰り返し反 対を述べました。青木 (幹雄) 参議院幹事長が「一 つ一つ官邸と党が対立している構図は良くない」 と窘めました。道路公団などいろいろな問題で官 邸と党が対立していましたから。総理は改めて詰 めることを指示されました。17時より党五役会議 を再開すると一旦連絡した後，それを取り消した のですが, 関係者は続々官邸に集まり始めました。 今でも覚えていますが, 当時の狭い総理執務室内 に, 偉い方々が椅子を並べて座っておられました。 秘書官は後ろに立っていました。かなり時間をか けて話し合いが行われ，これでまとまるのかなと 心配しました。青木幹事長は「時間をかけるのは 良くない。総理が外出される前に決めるべき」と 言われました。麻生政調会長は「党は平成15年度 から 3 割にすることは飲む。しかし文言上書けな い」と言われました。麻生政調会長は, 電話で伊 吹（文明）議員とやり取りをされました。なぜ伊 吹さんとやり取りをされたのかは分かりません。 麻生さんとしては, 一言断っておいたほうがいい と判断されたのだと思います。そして，文言上は 
「必要な時に引き上げる」と書くことになりまし た。そして，「必要な時」については「保険財政 の状況によって平成15年度も平成16（2004）年度 もあり得る」と誰かがおっしゃって, 総理は黙っ ていました。

それから, 予定より 1 時間遅れて政府与党社会 保障改革協議会が開かれました。丹羽，長勢議員 も参加されました。「コピーが間に合うかと焦る」 とメモに書いてありました。それから，山崎幹事 長が老人医療費の「抑制」を「適正化」に修正す るよう指示されました。保守党の井上（喜一）議 員から「必要な時とはどういう意味か」と聞かれ， 福田官房長官が「平成15年度から 3 割に引き上げ ることとし，法律に明記することです」と明確に 答えました。座談会録でもありましたがバ夕バ夕 している中，明確に答えられたのが大きなきっか けになったと思います。

翌日の11月30日，予算編成基本方針の政府案に は，竹島副長官補の指示で「3 割負担は平成15年 度から実施する」ということと「伸び率抑制を法 律に明記する」ということが明記されることにな りました。財務省は伸び率管理を一生懸命推して いましたが，私どもは非常に難しい仕組みだと考 えていました。伸び率が当初の予定よりも上回っ た時にどうするのか。ドイツのように総額請負制 のような形にするのか, 翌年取り戻すのか。理論 的には分かるのですが，行政上，厚生労働省はど うするのか。以前, 厚生労働省の方とお話しした 時も,「理論上はあり得るが，法律に書いて管理 するのは非常に難しい」と教えられました。スロー ガンとしてはよく分かるのですが，行政的にうま くできるのかと感じていました。総理と話した時 も，「そうだよな」と。伸び率管理については, 診療報酬の引き下げ， 3 割負担に比べると関心の 度合いが違っていたという感じもします。

そして，この予算編成基本方針の政府案は，自 民党の政策審議会をクリアーしたのですが, 総務 会では，本来，総務会に出ないはずの竹島副長官
補が出て，がんばって発言されていました。総務 会長に「もういい」と言われるくらいでしたね。 丹羽総務及び社会部会メンバーが「政府案は昨日 の合意文書と違う」と怒り, 竹島副長官補が孤軍 奮闘したものの認められず，再度諮ることになり ました。それを聞かれた総理は「実体が変わるの ではない。表現だけだろう。却って抵抗勢力がはっ きりしてよい」と言われ，ぶら下がり会見で「抵 抗勢力は健在なり」とコメントされました。

12月 1 日には総合規制改革会議の報告書が総理 に手交されました。医療分野では，205円ルール の廃止, レセプトの電子化, 保険者の審査の在り 方など, 総理が厚生大臣であった時からの懸案事 項が記載されており，総理も納得されました。

12月15日の朝だったと思いますが，診療報酬引 き下げについて大塚局長から電話連絡をいただき ました。全体で $\triangle 2.7 \%$, 薬価で $\triangle 1.4 \%$, 技術料 で $\triangle 1.3 \%$ で決まったと。総理が登庁される前に 電話したところ,「分かった」と一言言われました。 座談会録を見たところ, 大塚局長から「過去最高」 ということが総理に伝えられていたようですね。 総理の頭にはそれがあったのだと思います。 2.6 を超える2.7になったので，私には「分かった」 とだけ言われたのかなと推測しました。3 割負担 の実施時期について, 総理は2003年度からと考え ていたわけですが，丹羽さんなどは反対していま した。

2002（平成14）年 1月の時点でも，自民党の丹 羽議員らが依然として 3 割負担に反対し, 保険料 の引き上げを主張していました。総理は, 丹羽議 員と懇意の坂口大臣が迷っているのでないかとの 話を耳にされて，23日に総理から丹吳へ，「総理 の方針は変わらない。大臣は発言を慎重にするよ うに」と近藤次官に伝えるよう指示がありました。 厚生省の記録では, 総理から近藤次官に電話が あったとされていますが, この頃, 総理は携帯電 話を使っていなくて, 政務秘書官の飯島（勲）さ んや総理執務室の大塚（和子）さんに「誰々に電 
話してくれ」と指示していました。この時，近藤 次官に電話するよう言われたタイミングで私はい ませんでした。ただここういうことを自分に言わ れたことは覚えています。近藤次官は，私に「大 臣には伝えます。しかしこのままでは激突になり， 間に入る厚生労働省としては困ったことになる」 と当惑したコメントをされた, とメモにあります。 そして 1 月 24 日, ぶら下がり会見で, 3 割負担 への引き上げに自民党が反対している状況につい て聞かれ，総理は「自民党はあまり医師会寄りの 発言をせず，国民全体のことを考えて欲しい」と 答えられました。

2 月 4 日に第 154 回国会で施政方針演説が行わ れました。そこで,「特に医療制度は, 厳しい医 療保険財政の下，持続可能な制度にしていくため 改革が待ったなしです。患者, 医療保険料を負担 する加入者, 医療機関の三者がそれぞれ痛みを分 かち合う『三方一両損』の方針の下, 聖域は一切 認めず，これまでにない診療報酬の引き下げ，高 齢者医療を始めとする給付と負担の見直しなど思 い切った改革を行うこととしました。患者本位の 医療の実現を目指し, 診療報酬や医療機関情報の 開示などの規制改革を推進します」という発言を されました。

2 月11日には, 三幹三政会議に官房長官, 坂口 大臣，安倍副長官も出席して話し合いが行われま した。三幹事長から総理の意向に基づく収拾案が 示されましたが, 麻生政調会長が「ここで『はい』 というと自分が七転八倒する」と言って, 一旦党 本部に戻られました。そして，伊吹議員，長勢議 員と相談し, 丹羽議員に電話連絡をした上で戻っ てこられました。そして，全員でサインをして OKとなりました。官房長官が戻ってきて総理に 報告しました。総理は「自分から一昨日神崎（武 法）代表に，そして昨日は坂口，冬柴（鐵三）議 員に電話した。自民党内に抵抗する議員もいるだ ろうが，公明党がOKしたので時間の問題であろ う」とコメントされました。
2 月12日になり，閣議前に総理が坂口大臣と会 われ，大臣は「抜本改革は自分の責任でやる。省 内に本部を作り, 自分が本部長になる。また今夕 麻生政調会長, 丹羽議員と会う」と言われ, 総理 は「お願いします」とおっしゃいました。

一方で, 自民党社会部会は納得せず, 総務会で は何人かの議員から問題視する発言があったそう です。

2 月25日に衆議院予算委員会で医療問題集中審 議が開かれ， 3 割負担と抜本改革を両方実現する ことができるのかと問われた時, 総理は「自分の これまでの厚生大臣の経験から判断し, 法律に抜 本改革をやると明記するので二鬼は追える。最も 大事なのは政治の意思すなわち総理の意思であ る」と答弁されました。

後は法案の審議に関する括話です。その後，4 月 5 日に坪井会長が会長再選報告のため, 総理官 邸にいらっしゃいました。坪井会長は「改革に抵 抗が大きいことを実感しました。しかしやらなく てはいけないことなので仕方ありません」と, 総 理にとってはありがたいご発言をされました。

そこから 7 月26日の参議院本会議で健保法改正 案が可決成立したという流れです。以上が私のメ モにあったものでございます。

江利川 大変詳しくご丁寧なお話をありがとう ございます。

三谷 2001 年 6 月から 7 月までの間の動きはど のようなものでしたか。

丹吳 あまり記録がありませんでした。当然, 諮問会議の事務方との話があったでしょうけれど も。無かったわけではなく, 私の個人的なメモに は残っていなかったということでご理解をいただ きたいと思います。

\section{小泉総理の強い意思と実行力}

新田 詳細にお話しくださりありがとうござい ました。続いて質問票に即して，いくつかお尋ね いたします。2002（平成14）年改正をどのように 
御覧になっておられたか，印象的だったエピソー ドや特に重要な役割を果たした方についてお話し いただけますでしょうか。

丹吳 まず, 総理の強い意思, 実行力が印象に あります。2001（平成13）年 4月26日に総理にな り，「自民党をぶっ壊す」とおっしゃった。ご本 人は「『自民党が変わらなければ, ぶっ壊す』と言っ たのだ, ストレートに言ったわけではない」とおっ しゃいますが。それで参議院選挙も大勝し, 青木 参議院幹事長などがサポートしてくださるように なりました。「改革をしなければならない, 来年 は選挙がないから」とはおっしゃるものの，やは り選挙に勝って国民の支持をもらったというのは 総理にとって非常に力強い後ろ盾でした。総理は, 「中長期的なあるべき姿を見て改革を進めなけれ ばならない時期に来ている」と考えておられまし た。そして、「私が厚生大臣だった時の課題がそ のままではないか」と。総理になった時に, 厚生 大臣の時にできなかったことをやるのは自分の一 つの責務であるという印象も強かったのだと思い ます。

総理が橋本さんと連絡を取った記憶が全くあり ません。プライベートに電話されたかどうかまで は分かりませんが。総理は道路公団だけでなく, 特殊法人全体について見直すという意思を持って いらっしゃいました。住宅金融公庫など政府関係 金融機関についても, 見直しが必要なものは見直 すと。一方, 橋本さんは, 自民党の行政改革推進 本部最高顧問だったと思います。総理が「政府関 係金融機関も直すべきところは直さないといけな い」と言った時期は, ITバブルが弾けて, 経済 状況が悪くなってきているところでした。橋本さ んが「経済状況が悪い時に, それは無理だ」と言っ て, 結構厳しいやり取りになりました。総理が「党 は党でそれで結構です。政府は政府で改革案を国 会に出します」と言い, 山崎幹事長が,「まあま あそうは言わずに」といったことがありました。 丹羽さんとも直接はほとんど話していないと思い
ます。厚生労働省は大変だったのではないかと思 います。いずれにしても, 総理の実行力は非常に 強く印象に残っています。

それから，竹島さんがやはり，医療制度改革だ けでなく道路公団なども含めて, 副長官補として 支えてくださったと思います。先ほどの話でもあ りましたが, 自民党の総務部会で叱られつつも一 人で話し続けておられました。

新田 丹呉さんが小泉総理と医療保険制度改革 をめぐってご議論されたことはあったのでしょう か。総理の発言で印象に残っていることはありま すか。

丹吳 総理の改革についての発言では, 「自分 が厚生大臣の時に決めたことがなされていない」 といったお話が記憶に残っていますね。皆保険に ついては，絶対に維持しなくてはいけないという 強い信念をお持ちでした。ただ，「皆保険が維持 できなくなるのでないか。皆保険を守るために改 革が必要」という思いを持っていらっしゃいまし た。そのほかには,「来年は選挙がないからしっ かりとした改革をやるチャンスだ」という言葉も 記憶に残っています。「あるべき姿から考えるべ きだ」という言葉については，ほかの案件でも同 じような言い方をされていました。それから「三 方一両損」,「患者本位」という言葉もありました ね。

それから, 折に触れて, 総理に参考意見を求め られたりすることもあり，私なりにお答えしまし た。厚生省から官邸に香取 (照幸) さんが参事官 としてこられて，いろいろサポートしてくれました。

新田この時の診療報酬改定では,「本体 $\triangle$

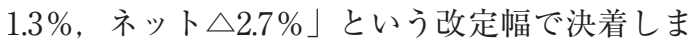
した。改定率の決定過程で小泉総理はどのような 役割を果たされたのでしょうか。

丹吳 改定幅について, 総理から具体的に指示 をされた記憶はありません。大塚局長から教えて 頂いた話を伝えたところ，「分かった」と。その 前に過去最大の引き下げ幅であることをご存知 
だったようですね。

新田 秘書官になられてからは官邸のお立場で すが，財務省のことに丹呉さんが直接関わられた ということはありましたか。

丹吳 あれは杉本 (和行 - 当時財務省主計局次 長）さん，田中一穂主計官が担当していました。

新田「医療制度改革の論点」などは財務省の 中で考えられたということですよね。丹呉さんは， その時は秘書官というお立場でしたし。

それから，竹島さんががんばられたのは，やは り11月30日の自民党総務会でしょうか。

丹吳 総務会ですね。

新田私も当時, 竹島さんが奮闘されて総務会 から追い出されそうになったという話をお伺いし た記憶があります。予算編成基本方針を固める過 程でこういう議論が行われたのですね。

江利川 あの時, 私も内閣府の官房長として総 務会に出ていて，総務会長が「ここでしゃべるの は国会議員だけだ」と言ったのですが，制止を聞 かずに総理のお考えはこうです，と竹島さんが全 部話したのですよね。すごいなと思いました。

丹吳 福田官房長官が「平成15（2003）年度か ら 3 割」と言ったのは, やや意外でした。安倍さ んは副長官で，もともと社会保障もやられていま したし，関心もおありでした。

江利川 官房副長官になる直前は自民党の社会 部会長でしたね。

丹吳 福田官房長官は非常にタイムリーに発言 してくださいました。それで官房長官まで含めて 官邸の意思が統一されていることが伝わったと思 います。

新田 厚生省の方々の括では，「よく聞こえ なくて，官房長官が本当に言われたのかどうか分 からない」ということでしたが，丹吳さんはお聞 きになったということですね。

江利川「適当な時期」をめぐって, 官邸サイ ドは翌年の 4 月 1 日から，自民党は「まさに『適 当な時期』であって来年とは限らない」という違
いがありましたね。そこで総理と橋本さんが話し 合われたということは。

丹比 私の記憶ではないです。

江利川そうですか。

丹吳 それだけではなくて，橋本さんとはあま り話をされていなかったですね。

新田 お二人の相性といったこともあったので しょうか。座談会でも, 目の前で総理と橋本さん が話し合われたという話は出てこなかったですね。

丹吳 目の前でも, 電話でも, ですね。丹羽さ んとも話はされていません。

江利川やはり山崎幹事長ですかね。

丹吳 そうですね。総理は厚生大臣を 3 回務め ておられたので，自分なりのお考えがしっかりあ りました。これはこうだと。坪井会長とは仲が良 いというか，懇意でしたね。総理はそこまでおっ しゃいませんでしたが，私どもは坪井会長にいろ いろ教えていただいたので，会長の立場を悪くし ないようにと思っていたら，会長がストレートに 「株式会社はダメだけれども，こっちはやります」 と言ってくださりました。

江利川 そうですか。

丹吳 坪井会長が「薬価には関与しない。政府 と製薬業界でやればよい」と。

新田 そこまで言われたのですか。

江利川 薬算定方式が変わって薬価差は小さく なってはいましたが，それでも診療報酬の改定の 財源になっていますよね。この時は診療報酬も含 改定の大枠が決まっていたからでしょうか。

丹吳 それもマイナスにすると。いつもの状況 ではなくて，この時だからこそこういう発言をさ れたのだと思いますね。

\section{医師不足問題に対する小泉総理の認識}

新田 そのほか, ご印象に残っていることはあ りますか。

丹吳 ある時期から, 医師が不足しているとい う話になり，総理は国会でも追及されました。厚 
生労働省からどなたが説明に来たのか覚えていま せんが，総理が怒り始めましてね。「俺にそんな ことは全く言わなかったじゃないか。3回も厚生 大臣をやっているのに。俺が大臣の時は，むしろ 余っていると言っていたではないか。いつから足 りなくなったのだ」と厳しい口調で叱られました。

江利川 私が厚生労働省の事務次官に戻ったの は安倍内閣の時で, 福田内閣に代わる直前でした。 厚生労働大臣は外添（要一）議員でした。今のお 話より時期が少し後ですが, 外添大臣が医師不足 だと言い始めたのです。言い始めたのは, 某大学 教授の話を聞いて，という噂というか，そんな話 がありましたね。

丹㕵 仙谷（由人）先生にも。

江利川 直接は知りませんが, その人は仙谷先 生にも近いという噂もありました。

丹吳 仙谷先生に国会で訊かれましてね。驚き ましたよ。絶対数が不足しているのかと。偏在と いう話ではなくて, 絶対数が不足すると。

江利川私も気になって医政局長に尋ねたら, 「いずれはオーバーするので抑えないといけませ んが，当面は不足する期間があります」というこ とでした。「期間を限れば不足する」ということ ですね。「今まで不足はないと言ってきたではな いか」と話したのですが。

丹吳 むしろ余っていると。

江利川「科による偏在はあるけれども，医師 数そのものが不足しているとは言ってなかったで はないか」と。しかし，「今の枠で養成すると， 何年間かは不足が生じます」ということでしたね。 どこかからそんな話が仙谷さんに伝わって，質問 となったのかもしれません。

丹吳 それで総理のところへ来てもらって説明 したところ，その方は総理が厚生大臣の時にした 説明を知らなかったのでしょうね。

江利川 多分, その時の医政局長だと思います が, 知らなかったのかもしれません。そういうこ とがありましたか。
禁煙治療の保険適用をめぐる小泉総理の認識

丹吳 それから水田 (邦雄) さんが厚生労働省 保険局長で，木下（賢志）さんが官邸付きの参事 官であった時, 総理に厚生労働省が禁煙治療を保 険適用にしたいと言ってきていますと話したら， 「えっ」と。「タバコに警告文書があるのだから， 禁煙治療は自助の世界だ。なぜ共助の保険適用を するのか」と。「タバコを吸ったら病気になると 書いてあるではないか。なぜ保険でやるのか」と。 小泉さんらしい考え方でした。

江利川禁煙の薬ができたのは, 私が保険局の 企画課長だった時です。薬事審議会としては薬と して承認をして，保険点数をつけるという話でし た。私は「効果があるのなら, 薬として承認する のは構わない。しかし, 禁煙は自力でやるものな ので, 医療保険の対象にするのはおかしい」と反 対して，保険適用を認めなかったのです。しばら く認めない時期があって, どこかで認めたのです ね。

丹吳「呼びましょうか」と総理に言ったら,「ま あいいや」と。

江利川 禁煙外来ができたので, 時代が変わっ たのだなと思いました。

丹吳「あるべき姿から考えろ」というところ から見ると, 自助の世界ですからね。薬は薬とし て認めればいいと思いますが。

江利川 保険で見るかどうかは別問題ですから ね。

丹吳 薬務局と保険局も。薬として認可される と当然保険適用だと。そこはワンクッションある はずだと我々は何度も言っているのですが，力不 足で。

江利川 1 回ではありますが, 私はやったので すけれどもね。

新田 日本の場合は医療自体と保険診療とがほ とんど重なっているので，イコールに考えてしま うところもあるのですかね。そもそもは別だとい う議論はなかなかぴんと来ない。 
江利川 私は自力で禁煙しました。

丹吳 総理も「俺だってタバコを吸っていたん だ」と。後で外資系の製薬会社が後乃にいたんだ ということを厚生省の人に教えて頂きました。あ あやっぱりそういうことで，と。

江利川 なるほどね。それは知りませんでした。

\section{、日本医師会と厚労族議員との関係性}

三谷 医師会長はどういったお話をされていた のでしょうか。

丹吳 振り返って,「いろいろありがとうござ いました」と。医師会サイドというか, 坪井会長 がどうご覧になっていたのか，というお話をされ ました。その前に総理のところへ行って，かなり はっきりと「1800億円は診療報酬で出します。皆 保険も守ります。ただ，混合診療と自己負担の引 上げは反対」と伝えています。もともとはっきり 物を言う方ではありましたが。

島崎 座談会は必ずしも時系列に整理されてい ませんが，今改めてお話しいただいたことを重ね 合わせると，この時こうだったのかということが よく分かりました。

丹吳 医師会は医師会で新しい時代に向けて考 えていることがありました。自民党内の意見すべ てについて，個人的にも医師会としても賛成して いるわけではないのに，「自民党イコール医師会」 と考えられているのが，と。「なんでも医師会， 医師会と書かれて，抵抗勢力だと新聞等で書かれ てしまうけれども，我々は実は違うんだ」と。

島崎 医師会が単なる利益団体に仕立てられて しまったことに対する不満があったというわけで すね。

\section{総理と族議員の板挟み状態の厚生労働省}

島崎 それから, 坂口大臣と丹羽先生が懇意で, 2002 (平成14）年 1 月23日, 総理の命を受け丹呉 さんから近藤次官に「大臣は発言を慎重にするよ うに」と伝えたとのお話がありました。私の記憶
だと,もう少し緊迫した場面もあったと思います。 2 月 5 日の新聞に,「小泉総理が近藤次官に『ふ らふらするな』と伝えた」という趣旨の記事が載つ ています。1月23日だけでなく 2 月 4 日には総理 が次官に電話されたのではないかと思うのですが。

丹吳 私どももほかの案件があって, いろいろ 説明を聞いたりしているので, 総理の電話をすべ てフォローできていないところはあります。近藤 次官か坂口大臣に対してそういう話があったとい うご記憶があるのであれば，それは事実なのだと 思います。

島崎 朝の政府委員室（今の国会連絡室）のレ クチャーの時でした。理由はよく覚えていません が，近藤次官がその場にいらっしゃったのです。 普段はひょうひょうとしていらっしゃるのに，電 話から戻ってこられた時に緊張が残っていたので す。「誰からだったのですか」と聞いたのですが, はっきりおっしゃいませんでした。ただ，後から 電話を取り次いだ政府委員室の人から聞いたとこ ろ, 総理からの電話であったとのことでした。私 の記憶違いかもしれませんが，総理は施政方針演 説でも明確に言っているのに大臣や省は何をふら ふらしているのだと苛立っておられたのではない かと思います。一方，坂口大臣は板挟み状態で恼 みは大きかったと思います。

丹吳 結果として 2 月 12 日に坂口大臣がいらっ しゃって，「抜本改革は自分の責任でやります。 省内に本部を置いて，自分が本部長になります」 と。

新田 3 月に発足するわけですよね。

島崎 官邸サイドから見ると，「これまで一体 何をやっているんだ」という感じはあったのかな と思います。

丹吳 神崎さんや冬柴さんに電話して, 公明党 の上のほうの人は分かっていたはずなのに，厚生 労働大臣である坂口さんがどうしてだと。

新田 ちょっとふらついたように感じられたの かもしれませんね。 


\section{人事異動をめぐる舞台裏}

江利川 余談ですが, 香取さんは, 1 月の人事 異動で新設の内閣府の経済財政諮問会議担当の参 事官となりましたが，4月に小泉内閣が発足し， しばらくして, 古川 (貞二郎) 副長官から「香取 さんを官邸にという話があるのだが，異動したば かりだから移すのは難しいかな」と話がありまし た。私は，「人事ですからできますが，この際， 官邸に総理秘書官を出していない省庁でよく国会

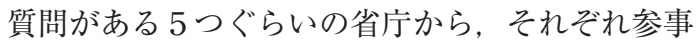
官クラスの人を官邸に出向させて, その中に香取 さんを入れるのはどうですか」と答えたら，それ はいいアイデアだと。

丹吳 本当に助かりました。

江利川 本当に丹呉さんの担当範囲は広かった ですから。一般論として, 各省からの参事官を増 やしたことは官邸の機能強化に役に立ったのでは ないかなと思います。その後も続いていますね。

丹吳 それはもう助かりました。この時はいろ いろなことが並行して走っていましたから。予算 そのものもありましたし。

\section{規制改革に対する総理の認識}

島崎 混合診療の規制緩和, 株式会社の医療機 関参入, 保険者による直接審査など, この当時, 規制改革の動きも活発でした。1990年代（平成 2 〜 11年) から2000年代 (平成12〜21年) 初頭には, 日本に限らずヨーロッパ諸国でも, ニューパブ リックマネジメントとか「官から民へ」という動 きがありましたね。経済規制と安全規制は一緒く たに論じることはできませんし，医師会も警戒し ていたと思います。総理としては，基本的に規制 改革は断固やるべきだというお考えだったので しょうか。

丹吳 そうですね。民間でできることは民間で
やる，という感じでしたね。農業や高度医療。奥 田さんではないですが，言われてみるとだいぶ民 間が進出してきているではないかと。それならば きちんと株式会社の算入を認めればいいではない かと。道路公団も民営化, というか。国債の発行 は30兆円までだと。税収が50兆円あれば30兆円だ という話でしたが。竹中さんのアドバイスもあり ましたが，規制改革で経済を活性化させると。観 光もそうでした。

江利川 500万人くらいだったのを倍にすると。

丹吳 1000 万人にする。そうすれば地域も活 性化するし, 外国人観光客が来て買い物をすれば 消費も増える。それに対する努力が足りないと。 できるだけ予算を使わない, 規制改革, 第三の道 でやれることはやろうというお考えでした。

新田 小泉総理の時に大きく変わりましたよね。

丹吳 厚生大臣を 3 回もやりましたから, 厚生 労働省に愛着があったというか。

江利川それはありがたかったですよね。先日 の大塚さんの話によると, 小泉総理は, かなり早 い段階から，診療報酬（本体・技術料）の引き下 げの意向を決めておられ，引き下げ幅も過去最高 くらいの思い切ったことを考えておられたようで すね。

丹吳 それは今回資料を見て初めて分かりまし た。総理は何も言わないで,「分かった」と一言 だけおっしゃったので。それから1800億円のほう ですね。それで問題が解決すると。

島崎 先日の座談会と丹呉さんのお話を重ね合 わせてみるとよく分かりました。

新田 行政サイドではなく政治サイドから 2002 （平成14）年改正を見ると, こうやって物事は動 くのだということがよく分かりました。本当にき れいにまとめてお話をいただき，ありがとうござ いました。 